\title{
Effect of replacing soybean meal protein with jojoba seed meal in diets of growing mono-sex Nile tilapia (Oreochormis niloticus) on growth performance and nutrient utilization
}

\author{
Nabil F. Abd El-Hakim ${ }^{1}$; Mohamed E. Lashin ${ }^{1}$; Hayam D. Tonsy ${ }^{2}$; \\ Samay.H. Mohmoud ${ }^{2}$ and Mostafa K. Sayed ${ }^{2}$
}

1-Department of Animal Production, Faculty of Agriculture, El -Azhar Univ. Cairo, Egypt.

2- Animal Production Researcher Institute, Agricult. Research Center, Dokki, Giza, Egypt.

\begin{abstract}
The study aimed to investigate the effect of replacing soybean meal (SBM) 1 protein by treated Jojoba seed meal (JSM) in diets of Nile tilapia (Oreochromis niloticus) on growth performance, nutrient utilization, carcass traits, body chemical composition and digestibility of nutrients of Nile tilapia, reared under semi-intensive conditions in fiber glass tanks. The experimental tanks $(1 \mathrm{~m} \times 2 \mathrm{~m} \times 0.5 \mathrm{~m})$ each contains one $\mathrm{m}^{3}$ water volume, were used in this study. The three tanks represented three dietary treatments, the first tank served as a control, where the experimental fish were fed on the control diet containing soybean meal (SBM) as a source of plant protein with fish meal as a source of animal protein. Fish of the second and third tanks were fed on diets containing the Jojoba seed meal (JSM) to replace 25 and 50\% of SBM protein, respectively. The experimental tanks were stocked with Nile tilapia fingerlings at a density of 50 individuals in each tank. The experimental period lasted 18 weeks after start. The initial weight of the experimental fish ranged between $7.20 \pm 0.09 \mathrm{~g}$ and 7.5 $\pm 0.08 \mathrm{~g}$ and they were allotted randomly into the experimental tanks. The experimental rations contained 30\% crude protein and $4500 \mathrm{kcal}$ gross energy/ $\mathrm{kg}$ diet and the experimental diets were formulated to be almost isonitrogenous isocaloric. The experimental diets were fed at a rate of $3 \%$ of tank fish biomass 6 days a week, in two portions, at 9:00 a.m. and 3:00 p.m.

The results of this study revealed that, the highest $(\mathrm{P}<0.05)$ final weights, specific growth rate, protein and nutrient utilization were recorded by JSM $25 \%$ group followed by the control group and the JSM 50\% groups, respectively. The same trend was observed in apparent digestibility coefficients. Therefore, these results suggest that up to $25 \%$ of soybean meal can be replaced by treaded Jojoba seed meal protein in Nile tilapia diets without any adverse effect on growth performance, feed and protein utilization, body composition and digestibility of nutrients.
\end{abstract}

Keywords: Jojoba seed meal, Nile tilapia, growth, body composition, digestibility, economical efficiency. 


\section{INTRODUCTION}

Feed costs represent almost over $60 \%$ to $70 \%$ of the production costs in fish culture. Tilapia is the most cultured fish species in Egypt and reduction in feed costs are essential to expand its culture in the country especially at semi and intensive levels.

There is substantial interest in substituting the expensive dietary ingredients by cheaper cost feed ingredients in Nile tilapia diets with maintaining growth performance as high as possible. Soybean meal is a plant protein, which could substitute fishmeal in fish diet, but it is now expensive and its prices is rising due to the high demand on this ingredient.

Therefore, it is important to search for other non-traditional available protein sources, which could be incorporated in fish diets without adverse effects on fish growth or efficiency of diet utilization.

Jojoba meal represents one of the non-traditional plant protein sources; however, several trails have demonstrated growth retardation in animals consuming diets supplemented with Jojoba meal (Booth et al., 1974; Verbiscar et al., 1980; Ali, 2004 ; Motawe, 2005).

Jojoba (Simmondsia chinesis) as a dioecious desert shrub that grows on arid or semi arid regions is being cultivated to provide a renewable source of a unique high-quality oil (Sabien et al., 1997). Several advantages are favoring jojoba seeds to be grown in Egypt such as limited water requirements, high seed yield in new reclaimed soils and relatively high oil content, (50\% ) (Wisniak, 1987). The meal remaining after the oil extraction, contains high protein level (approximately 30\%) and therefore should be of interest for livestock producers as a feed supplement (Motawe, 2005). The major problem with using jojoba meal is the high level of anti-nutritive compounds; that can be mitigated by various treatments. However, this is attributed by most workers to the presence of the cacogenic compounds normally, simmondsin and simmondsin-2-ferulate (Elliger et al., 1973 and 1974; Van Boven et al., 2000). Compounds other than simmondsin including poly phenolics, phytic acid and trypsin inhibitors, may be contributing to impaired feed intake and body weight gain of animals fed diets contain Jojoba seeds meal (Booth et al., 1974 ;Cokelaere et al., 1992; Abbott et al., 2004). Some authors consider simmondsins to be toxic, probably after metabolism by gut micro organisms (Booth et al., 1974; Verbiscar et al., 1980). Bellirou et al. (2005) reported that elimination of jojoba seed meal anti-national factors could be done by different methods, including solvent extraction, heat, chemical treatment and microbial fermentation. Simmondsin (Di methyl simmondsin) is a natural compound in the seed of jojoba plant that can suppress the appetites of animals when incorporated in food formulas. Simmondsin and several of its analogs are present at 5-7\% level in jojoba seed and remain in the press cake.

Also, Ali (2004) studied the effect of replacement of soybean meal with Jojoba hexan iso-propanol treated meal JHSO or with Jojoba meal treated with 
hexan and water JHW at levels 25,50 and $75 \%$ on growth performance of Nile tilapia fingerlings (60 and 0.33 grams initial weight) in the first and second trials, respectively for 20 weeks. The author reported that inclusion of JHSO or JHW in Nile tilapia diets decreased final weight, total weight gain and specific growth rate and the decrease was more pronounced at higher replacement levels. The same author reported also, that incorporation of JHSO or JHW in growing Nile tilapia diets, increased the average feed intake; crude protein intake and gross energy intake. He added that feed conversion ratio (FCR) was elevated negatively with increasing the replacement levels of soybean meal with JHSO or JHW. The same trend was observed with protein efficiency ratio and energy utilization. The author concluded that JHSAO or JHW could replace soybean protein in Nile tilapia diets up to $25 \%$. Khalel et al (2008) reported that chemically treated Jojoba meal by iso propanol could be used at $10 \%$ of concentrate feed mixtures without any adverse effects on sheep performance.

The present investigation aimed to evaluate the effect of incorporation of Jojoba meal in tilapia diets at levels of 25 and $50 \%$ to substitute soybean protein on growth performance, nutrient utilization and carcass traits of growing Nile tilapia.

\section{MATERIALS AND METHODS}

This study was carried out at Fish Experimental Station belonging to Animal Production Department, Faculty of Agriculture, Al-Azhar University, Cairo, Egypt. The experimental rearing system consisted of series of 3 rectangular fiber glass tanks, each of total volume of one $\mathrm{m}^{3}(1 \mathrm{~m} \times 2 \mathrm{~m} \times 0.5 \mathrm{~m})$ supplied with dechlorinated tap water through a closed water recycling system connected with mechanical filters. Tank water was aerated continuously using an air compressor. Water quality parameters in the experimental system were monitored daily according to the methods described by Boyed (1979) and the range for dissolved oxygen was 5-7.5 mg/l, total ammonia was $0.25-0.33 \mathrm{mg} / \mathrm{l}$, $\mathrm{pH}$ was $7.2-7.7$, nitrate $0.22-0.30 \mathrm{mg} / \mathrm{l}$ and average salinity was $0.2 \mathrm{ppt}$ in all experimental tanks. All tested water quality parameters were within the permissible levels for optimum growth of tilapia which was in accordance with the findings of El-Hammady (2001). Jojoba meal used in the present study was heated in open trays in an oven at $135^{\circ} \mathrm{C}$ for fifteen minutes then extracted with hexane 1:1 then extracted with isopropanol 1:1 for six hours.

\section{Experimental diets:}

Three diets were formulated (Table 1) where soybean meal protein T1 (basal diet) was replaced by protein of Jojoba meal protein at 25 (T2) and 50\% (T3) levels. Chemical composition and essential amino acids contents of the Jojoba meal, soybean meal and casein on DM basis are presented in Table (2). The experimental diets were formulated to contain almost 30.03\% crude protein and $4519.41 \mathrm{kcal}$ gross energy $/ \mathrm{kg}$ diets as presented in Table (1). Diets were prepared using the fine ground experimental Jojoba meal which was mixed with the other dietary feedstuffs. Twenty five percent of water was added to each 
dietary formula, then mixed thoroughly again and produced in pellets form ( 0.2 $\mathrm{cm}$ in diameter) using a mincing machine. The experimental dietary pellets were sun dried and stored in good storage conditions till the experimental start.

Table (1): Formulation and chemical composition of experimental diets (on DM basis).

\begin{tabular}{lccc}
\hline \multicolumn{1}{c}{ Item } & T1 & T2 & T3 \\
\hline Feed ingredients: & & & \\
Yellow corn & 38.0 & 31.25 & 24.50 \\
Fish meal & 14.0 & 14.70 & 15.40 \\
Soybean meal & 35.0 & 26.25 & 17.50 \\
Wheat bran & 10.0 & 10.0 & 10.0 \\
Jojoba meal & - & 14.8 & 29.60 \\
Vegetable oil & 1.5 & 1.5 & 1.50 \\
Fish premix* & 1.5 & 1.5 & 1.50 \\
Total & $\mathbf{1 0 0}$ & $\mathbf{1 0 0}$ & $\mathbf{1 0 0}$ \\
Chemical composition \%: & & & \\
DM & 92.0 & 91.80 & 90.0 \\
CP & 30.04 & 30.03 & 30.01 \\
EE & 4.83 & 5.21 & 5.72 \\
CF & 4.50 & 5.27 & 6.03 \\
Ash & 4.71 & 4.76 & 6.75 \\
NFE** & 55.92 & 54.73 & 51.49 \\
Gross energy (Kcal/kg)*** & 1500.67 & 4519.41 & 4538.15 \\
\hline
\end{tabular}

T1: Control T2: Jojoba 25\%. T3: Jojoba 50\%

*: (each 1 kg contains: vitamin A, 2.5 m.i.u.; vitamin $\mathrm{D}_{3}, 1.25$ m.i.u.; vitamin E. 125000 mg; vitamin $K$, 5000 mg; vitamin $B_{1}$, 7500mg; vitamin $B_{2}$, 5000 mg; vitamin $B_{6} ; 25000$ mg; vitamin $B_{2}, 10 \mathrm{mg}$; pantothenic acid, $10000 \mathrm{mg}$; Nicotinic acid, 100000; folic acid, $5000 \mathrm{mg}$; biotin, $750 \mathrm{mg}$; choline chloride, $2000000 \mathrm{mg}$; copper, $3000 \mathrm{mg}$; Iodine, 125 mg; Iron, 75000 mg; Manganese, 6000 mg; Zinc, 65000 mg; Selenium, 150 mg).

**: Calculate by difference

***: Estimated according to Jobling, (1983).Using the factor 5.65, 9.45 and 4 for crude protein, ether extract and carbohydrate, respectively

\section{Experimental fish:}

Monosex Nile tilapia fingerlings (Oreochromis niloticus), purchased from a private tilapia hatchery at Abbassa, Sharkiya governorate, were used in this study. A total number of 150 Nile tilapia fingerlings with an average initial body weight of 7.2-7.5 $\pm 0.08 \mathrm{~g}$ (Table 3 ) were randomly distributed into three experimental groups each represented one of the dietary treatments cited above and stocked in the experimental tanks at a rate $50 \mathrm{fish} / \mathrm{m}^{3}$. The experimental fish were individually weighed weekly during the course of the experiment to the nearest $0.1 \mathrm{~g}$ in order to adjust the feeding rate. Fish in the experimental groups were fed twice daily at $8.00 \mathrm{a}$.m. and $3.00 \mathrm{p} . \mathrm{m}$. on the corresponding experimental diets at a rate of $3 \%$ of fish biomass in two portion. The experimental period lasted 18 weeks after start. 
Table (2):Proximate analysis, chemical composition and essential amino acids composition of the tested Jojoba meal on (\%DM) compared with soybean meal and casein.

\begin{tabular}{|c|c|c|c|}
\hline Item & Jojoba meal & Soybean meal & Casein \\
\hline \% Dry matter & 93.17 & 90.80 & - \\
\hline \% Crude protein & 26.00 & 44.00 & 87.20 \\
\hline Ether extract & 4.5 & 1.10 & N.R \\
\hline Crude fiber & 10.5 & 7.30 & N.R \\
\hline Ash & 4.15 & 6.3 & N.R \\
\hline Nitrogen free extract & 54.85 & 41.3 & N.R \\
\hline Gross energy (kcal/kg) & 4508.25 & 4533.95 & N.R \\
\hline Arginine & 3.45 & 3.39 & 4.14 \\
\hline Threonine & 1.24 & 1.78 & 4.92 \\
\hline Histidine & 0.90 & 1.19 & 3.19 \\
\hline Isoleucine & 1.32 & 2.03 & 5.53 \\
\hline Leucine & 2.21 & 3.49 & 10.32 \\
\hline Lysine & 1.20 & 2.85 & 9.16 \\
\hline Methionine & 0.97 & 0.57 & 3.04 \\
\hline Phenylalanine & 1.21 & 2.22 & 5.69 \\
\hline Tryptophan & ND* & N.R** & ND* \\
\hline Valine & 2.08 & 2.02 & 7.41 \\
\hline Total Ess. AA\% & 14.58 & 19.54 & \\
\hline Chemical score (CS) & 13.10 & 18.75 & \\
\hline Essential amino acid index (EAAI) & 26.7 & 35.30 & \\
\hline First limiting amino acid (FLAA) & Lys. & Met. & \\
\hline Second limiting amino acid (SLAA) & Phe. & Vol. & \\
\hline Third limiting amino acid (TLAA) & Leu. & Lys. & \\
\hline
\end{tabular}

\section{Diets and fish proximate analysis:}

The tested diets as well as whole body samples were analyzed for crude protein (CP), ether extract (EE), ash and dry matter (DM) according to methods described by A.O.A.C. (1984). Analysis of amino acids in the Jojoba meal and soybean meal were done in the Central Laboratory for Feed and Feeding according to Winder and Eggum, (1966) (Table 2). Protein represents the most important nutrient in jojoba meal with respect to its potential as a livestock feed. Results in this table (2) reveal that Jojoba seed meal contains less lysine $(1.2 \%)$ and more methionine $(0.97 \%)$ compared to soybean meal $(2.85 \%$ and $0.57 \%$, respectively) which may indicate that the use of both meals in tilapia diets could satisfy tilapia requirements from both amino acids. Furthermore, soybean meal contains high level of total essential amino acids compared to Jojoba meal. On the other hand, Jaime (1987) reported that amino acids composition of Jojoba meal contains Lysine $(1.05 \%)$ and methionine $(0.19 \%)$ while the jojoba seed meal contains about $26-30 \%$. The chemical score results of jojoba meal is in harmony with their content of the first limiting amino acid (lysine). There is no information about chemical score and essential amino acid index for jojoba seed meal. 


\section{Digestibility trial:}

At the end of experimental period, a digestibility trial was carried out and the apparent digestibility coefficients of nutrients (ADC) for dry matter (DM), crude protein (CP), ether extract (EE) and nitrogen free extract (NFE) were determined using ash method as an inert marker according Sales and Janssens (2006). Apparent digestibility coefficients (ADC\%) of nutrients were calculated according to the following equation.

\section{Carcass traits:}

$$
\text { ADC (\%) }=100-\left[100 \times \frac{\% \text { marker in feed }}{\% \text { marker in feces }} \times \frac{\% \text { nutrient in feces }}{\% \text { nutrient in feed }}\right.
$$

At the end of the experimental period, four fish were taken randomly from each treatment and exposed to carcass test. In carcass test, fish body weight, scales weight, fins weight, viscera weight, head weight and flesh weight with bones and skin were recorded. All carcass traits were calculated as percentage of the fish body weight.

\section{Hepatosomatic index:}

Hepatosomatic index (HSI) was calculated as follow:

$$
\text { HSI }=100 \times \text { [liver weight }(\mathrm{g}) / \text { fish weight }(\mathrm{g})]
$$

Economical efficiency (EcE):

The economical efficiency was determined on the basis of feed and fingerlings costs.

$$
\text { Economical efficiency }=\frac{\text { Total income (L.E.) }}{\text { Total costs (L.E.) }} \times 100
$$

\section{Statistical analysis:}

Data obtained were statistically analyzed, using the SAS Program (1996) and the differences between means were evaluated by Duncan's multiple range test (Duncan, 1955).

\section{Growth performance and feed utilization:}

\section{RESULTS AND DISCUSSION}

Average of initial weights (g/fish) final weights (g); weight gains (g); and feed intake (g) are present in Table (3). The average initial weights had ranged between 7.20 to $7.50 \mathrm{~g}$ with insignificant differences $(\mathrm{P}<0.05)$ among the experimental groups. At termination of the experiment (18 weeks) averages of final weights of the control group ( $0 \%$ Jojoba meal ), $25 \%$ and $50 \%$ of Jojoba meal levels in replacement to soybean meal protein were 62.85, 65.24 and $56.26 \mathrm{~g}$, respectively. Gain in weight followed the same trend as final weight, being 55.35, 57.84 and 49.06g, respectively. The statistical evaluation of the results indicated that the Jojoba meal at 25\% level (T2) group and the control group had superior $(\mathrm{P}<0.05)$ final body weights and weight gains compared to Jojoba meal of $50 \%$ group, which showed the lowest $(\mathrm{P}<0.05)$ final weights and total weight gain. These results are in accordance with the findings of Ali (2004) 
who reported that incorporation of Jojoba meal extracted with iso-propanol or water depressed growth of growing Nile tilapia when replaced soybean meal protein at $75 \%$ level (22.5\% Jojoba meal in the diet).

The positive effects of Jojoba meal at $25 \%$ level in replacement to soybean meal protein observed in this study compared to that observed by Ali (2004) may be due to the fact that Jojoba meal used in the present study was treated with heat and extracted with hexane and iso-propanol which decreased simmodsin contents to a level that could not decrease the body weight of Nile tilapia (Boothe et al., 1974; Cotgageorge et al., 1978; Cokelaere et al., 1992; Ali, 2004).

Results Table (3) show that incorporation of Jojoba meal in replacement to SBM protein at 25 and 50\% levels had insignificant effects on tilapia feed intake. On the other hand, treated Jojoba meal at 50\% level increased significantly $(\mathrm{P}<0.05)$ negatively elevated feed conversion ratio compared to the $25 \%$ Jojoba meal protein. The same trend was observed with specific growth rate (SGR) where the control and 25\% Jojoba meal groups showed higher $(\mathrm{P}<0.05)$ SGR records compared with the $50 \%$ treated Jojoba meal group. Averages of protein efficiency ratio (PER) and protein productive value (PPV) of the control group and $25 \%$ treated Jojoba meal were significantly $(\mathrm{P}<0.05)$ higher than that of the $50 \%$ treated Jojoba meal group.

Table (3): Growth performance and feed utilization of Nile tilapia fed on experimental diets.

\begin{tabular}{lccc}
\hline \multicolumn{1}{c}{ Item } & T1 & T2 & T3 \\
\hline Initial average weight (g) & $7.50^{\mathrm{a}}$ & $7.40^{\mathrm{a}}$ & $7.20^{\mathrm{a}}$ \\
& \pm 0.08 & \pm 0.09 & \pm 0.08 \\
Final average weight (g) & $62.85^{\mathrm{a}}$ & $65.24^{\mathrm{a}}$ & $56.26^{\mathrm{b}}$ \\
& \pm 0.97 & \pm 0.77 & \pm 0.34 \\
Weight gain (g/fish) & $55.35^{\mathrm{a}}$ & $57.84^{\mathrm{a}}$ & $49.06^{\mathrm{b}}$ \\
& \pm 1.22 & \pm 0.98 & \pm 0.83 \\
Feed intake & $79.35^{\mathrm{a}}$ & $80.30^{\mathrm{a}}$ & $74.50^{\mathrm{a}}$ \\
& \pm 1.96 & \pm 1.84 & \pm 1.68 \\
Feed conversion ratio(FCR) & $1.43^{\mathrm{b}}$ & $1.39^{\mathrm{b}}$ & $1.52^{\mathrm{a}}$ \\
& \pm 0.04 & \pm 0.05 & \pm 0.08 \\
SGR (y/d) & $1.81^{\mathrm{a}}$ & $1.73^{\mathrm{a}}$ & $1.63^{\mathrm{b}}$ \\
& \pm 0.05 & \pm 0.06 & \pm 0.07 \\
PER & $2.32^{\mathrm{a}}$ & $2.40^{\mathrm{a}}$ & $2.19^{\mathrm{b}}$ \\
& \pm 0.08 & \pm 0.09 & \pm 0.08 \\
PPV\% & $31.12^{\mathrm{a}}$ & $32.10^{\mathrm{a}}$ & $24.24^{\mathrm{b}}$ \\
& \pm 1.07 & \pm 0.97 & \pm 0.35 \\
Condition factor (k) & $1.72^{\mathrm{a}}$ & $1.71^{\mathrm{a}}$ & $1.68^{\mathrm{a}}$ \\
\hline
\end{tabular}

a,b,c.... etc: means within the same column with different superscripts are significantly different $(\mathrm{P}<0.05)$.

Furthermore, results in Table (3) show that replacement of SBM protein by treated Jojoba meal protein at 25 or $50 \%$ levels released no significant effects on condition factor which indicate that fish in all treatment groups grow 
relatively in weight and length in similar manner. The negative effects of high levels (50\%) of Jojoba meal incorporation in replacement with SBM protein may be due to the fact that higher levels of treated Jojoba meal may still contain higher levels of simmondsin which is considered toxic for animals, beside the higher fiber contents in this meal (Eilliger et al., 1973, 1974 and Ali 2004).

\section{Whole body composition:}

Averages of whole body composition including dry matter (DM), crude protein (CP), ether extract (EE), nitrogen free extract (NFE) as percentage of (DM) and gross energy contents (kcal GE/kg DM) as affected with the dietary treatments at the start and end of the experimental period are presented in Table (4). Results revealed that DM, CP, EE, Ash and energy contents of tilapia whole bodies were 20.15, 59.62, 19.53, 20.85\% and 5214.2 Kcal GE/kg DM at the start of the experiment, respectively. Results reveled that DM, EE and ash contents in tilapia whole bodies at the end of the experimental period were significantly $(\mathrm{P}<0.05)$ higher in the treatment groups compared with the corresponding values at the experimental start except for CP. At the end of the experimental period, groups fed on the control and the 25\% treated Jojoba meal showed higher DM, CP and EE contents in the DM of whole bodies compared to the 50\% Jojoba meal group. On the other hand, the 50\% Jojoba meal group showed significantly $(\mathrm{P}<0.05)$ higher ash and NFE contents compared to the other treatment groups. Concerning whole bodies energy contents, the control group and the $25 \%$ Jojoba meal group showed higher $(\mathrm{P}<0.05)$ bodies energy contents compared to the $50 \%$ Jojoba group. These results are in agreement with the findings of Ali (2004) who reported that incorporation of $14.80 \%$ of Jojoba meal (in replacement of $25 \%$ of soybean meal protein) in Nile tilapia diets increased DM, CP and EE contents in whole fish bodies compared to higher levels (50\%or 75\%) of Jojoba meal in replacement of soybean protein .

Table (4): Effect of the dietary treatments on chemical composition of whole body of monosex Nile tilapia fingerlings (means \pm S.E.) as affected by dietary treatments.

\begin{tabular}{lcccccc}
\hline \multirow{2}{*}{ Item } & \multicolumn{5}{c}{ Chemical composition (as a percentage of DM) } \\
& DM \% & CP & EE & Ash & NFE & $\begin{array}{c}\text { Energy } \\
\text { (kcal GE/kg DM) }\end{array}$ \\
\hline At start of the experiment & $20.15^{\mathrm{c}}$ & $59.62^{\mathrm{a}}$ & $19.53^{\mathrm{d}}$ & $20.85^{\mathrm{b}}$ & - & $5214.12^{\mathrm{ab}}$ \\
& \pm 0.61 & \pm 0.31 & \pm 0.33 & \pm 0.43 & - & \pm 20.25 \\
At end to the experiment: & & & & & & \\
& $24.75^{\mathrm{a}}$ & $53.50^{\mathrm{b}}$ & $23.75^{\mathrm{a}}$ & $21.51^{\mathrm{b}}$ & $1.25^{\mathrm{b}}$ & $5317.13^{\mathrm{a}}$ \\
Control diets T1 & \pm 0.97 & \pm 0.45 & \pm 0.27 & \pm 0.24 & \pm 0.19 & \pm 18.76 \\
& $24.50^{\mathrm{a}}$ & $54.00^{\mathrm{b}}$ & $22.87^{\mathrm{b}}$ & $21.80^{\mathrm{b}}$ & $1.33^{\mathrm{b}}$ & $5265.42^{\mathrm{ab}}$ \\
Jojoba meal (25\%) T2 & \pm 0.95 & \pm 0.30 & \pm 0.20 & \pm 0.20 & \pm 0.21 & \pm 12.37 \\
& $22.00^{\mathrm{b}}$ & $50.75^{\mathrm{c}}$ & $21.80^{\mathrm{c}}$ & $25.37^{\mathrm{a}}$ & $2.08^{\mathrm{a}}$ & $5010.68^{\mathrm{c}}$ \\
Jojoba meal (25\%) T3 & \pm 0.20 & \pm 0.36 & \pm 0.31 & \pm 0.27 & \pm 0.22 & \pm 19.40 \\
\hline C.... etc: means within the same column with different superscripts are significantly different $(\mathrm{P}<0.05)$. \\
* Estimated according to Jobling (1983).
\end{tabular}




\section{Apparent nutrient digestibility coefficients:}

As presented in Table (5), averages of apparent digestibility coefficients (ADC) of DM and CP for dietary treatment groups T1, T2 and T3 were 89.48, 89.24 and $86.80 \%$ for DM and $74.74,74.25$ and $67.61 \%$ for CP, respectively. Results revealed that replacement of SBM protein with Jojoba meal at 25\% level had no significant effect on DM. ADC, while increasing the replacement level to $50 \%$ decreased them significantly.The same trend was observed with CP ADC, thus T3 group recorded lower $(\mathrm{P}<0.05)$ value compared to T1 and T2. On the other hand, replacement of SBM protein with Jojoba meal at 25 and $50 \%$ levels had no significant effects on EE, NFE and GE apparent digestibility coefficient. These results are in partial agreement with the findings of Nazmi (2007) who reported that replacing $30 \%$ of soybean protein with sunflower meal resulted in ADC for DM, CP, EE, NFE and GE of 89.92, 73.65, 88.76, 44.42 and 59.67\%, respectively. Results in Table (5) are also in agreement with the findings of Ali (2004) who reported that incorporation of iso-propanol extracted Jojoba meal at levels of 25, 50 and $75 \%$ in replacement to soybean protein in Nile tilapia diets improved protein efficiency ratio and apparent protein and energy utilization and the improvement was more pronounced at higher levels compared to the control group.

Table (5): Apparent nutrient digestibility coefficient (ADC\%) of the experimental diets by using an ash as internal digestive indicator (means \pm S.E.).

\begin{tabular}{|l|c|c|c|c|c|}
\hline \multirow{2}{*}{\multicolumn{1}{|c|}{ Item }} & \multicolumn{5}{|c|}{ ADC } \\
\cline { 2 - 6 } & DM & CP & EE & NFE & GE \\
\hline \multirow{2}{*}{ Control diets T1 } & $89.48^{\mathrm{a}}$ & $74.74^{\mathrm{a}}$ & $81.80^{\mathrm{a}}$ & $42.33^{\mathrm{a}}$ & $55.92^{\mathrm{a}}$ \\
& \pm 0.21 & \pm 1.53 & \pm 2.70 & \pm 2.58 & \pm 2.20 \\
\hline Jojoba meal (25\%) & $89.24^{\mathrm{a}}$ & $74.25^{\mathrm{a}}$ & $79.78^{\mathrm{a}}$ & $45.83^{\mathrm{a}}$ & $55.30^{\mathrm{a}}$ \\
T2 & \pm 0.73 & \pm 0.85 & \pm 4.45 & \pm 3.03 & \pm 2.44 \\
\hline Jojoba meal (50\%) & $86.80^{\mathrm{b}}$ & $67.61^{\mathrm{b}}$ & $79.42^{\mathrm{a}}$ & $47.23^{\mathrm{a}}$ & $53.41^{\mathrm{a}}$ \\
T3 & \pm 1.10 & \pm 1.53 & \pm 2.18 & \pm 5.15 & \pm 3.78 \\
\hline
\end{tabular}

a,b,c.... etc: means within the same column with different superscripts are significantly different $(\mathrm{P}<0.05)$.

\section{Carcass traits:}

Average of weights of fins, scales, viscera, head, hepato-somatic index (HSI) and flesh with bones of Nile tilapia as percentages of body weight are presented in Table (6). Results revealed that Jojoba meal at replacement levels of 25 and $50 \%$ of SBM protein increased $(\mathrm{P}<0.05)$ fins and scales percentages compared to the control group. Furthermore, Jojoba meal at $50 \%$ replacement level decreased significantly $(\mathrm{P}<0.05)$ viscera percentage and increased $(\mathrm{P}<0.05)$ head percentage compared to the control and the $25 \%$ Jojoba meal groups. Also, incorporation of Jojoba meal at 50\% level in replacement to SBM protein decreased significantly $(\mathrm{P}<0.05)$ HSI, while incorporation of Jojoba meal at both levels had no significant effects on flesh with bones percentages. These results are in agreement with the findings of Ali (2004). 
Table (6): Effect of the dietary treatment on carcass traits and hebatosomatic index of monosex

Nile tilapia fingerlings (means \pm S.E.).

\begin{tabular}{lcccccc}
\hline \multicolumn{1}{c}{ Item } & $\begin{array}{c}\text { Fins } \\
\text { \% }\end{array}$ & $\begin{array}{c}\text { Scales } \\
\text { \% }\end{array}$ & $\begin{array}{c}\text { Viscera } \\
\text { \% }\end{array}$ & $\begin{array}{c}\text { Head } \\
\text { \% }\end{array}$ & $\begin{array}{c}\text { HSI liver } \\
\text { \% }\end{array}$ & $\begin{array}{c}\text { Flesh } \pm \\
\text { Bones and } \\
\text { skin \% }\end{array}$ \\
\hline Control diets T1 & $2.39^{\mathrm{b}}$ & $2.95^{\mathrm{b}}$ & $9.55^{\mathrm{a}}$ & $22.72^{\mathrm{b}}$ & $1.82^{\mathrm{a}}$ & $60.57^{\mathrm{a}}$ \\
& \pm 0.25 & \pm 0.17 & \pm 0.38 & \pm 0.31 & \pm 0.18 & \pm 0.92 \\
Jojoba meal (25\%) T2 & $2.44^{\mathrm{a}}$ & $3.00^{\mathrm{a}}$ & $9.45^{\mathrm{a}}$ & $22.77^{\mathrm{b}}$ & $1.71^{\mathrm{ab}}$ & $60.63^{\mathrm{a}}$ \\
& \pm 0.19 & \pm 0.29 & \pm 0.32 & \pm 0.31 & \pm 0.28 & \pm 0.82 \\
Jojoba meal (25\%) T3 & $2.47^{\mathrm{a}}$ & $3.10^{\mathrm{a}}$ & $9.33^{\mathrm{b}}$ & $23.12^{\mathrm{a}}$ & $1.65^{\mathrm{b}}$ & $60.33^{\mathrm{a}}$ \\
\hline
\end{tabular}

a,b,c.... etc: means within the same column with different superscripts are significantly different $(\mathrm{P}<0.05)$.

\section{Economical efficiency:}

The economical efficiencies for all the experimental diets are presented in Table (7). The economical efficiency was determined on the basis of feed and fry costs, when all other costs are similar under the experimental conditions of the present study. Averages of revenues in LE for the control, Jojoba meal (25\%) and (50\%) were 5.20, 6.17 and 3.61 LE, respectively.

Table (7): Economical efficiency of the experimental diets.

\begin{tabular}{lccc}
\hline \multicolumn{1}{c}{ Item } & T1 & T2 & T3 \\
\hline Initial weight (kg)/tank & 0.375 & 0.370 & 0.360 \\
Final weight (kg/tank) & 3.143 & 3.262 & 2.813 \\
Total amount of feed intake (kg/tank) & 3.968 & 4.015 & 3.725 \\
Price of one kg ration (L.E.) & 1.810 & 1.790 & 1.760 \\
Total feed costs (L.E.) & 7.180 & 7.190 & 6.560 \\
Cost of the fingerlings/tank (L.E.) & 7.000 & 7.000 & 7.000 \\
Total costs (L.E.) & 14.180 & 14.190 & 13.560 \\
Total fish weight gain/tank (kg) & 2.768 & 2.892 & 2.453 \\
Sale price kg fish (L.E.) & 7.000 & 7.000 & 7.000 \\
Total income /tank for fish weight gain (L.E.) & 19.380 & 20.240 & 17.170 \\
Revenues (L.E.) & 5.200 & 6.05 & 3.610 \\
\% of the control & 100 & 116.35 & 69.42 \\
Economical efficiency\% & 136.670 & 142.640 & 126.620 \\
\hline
\end{tabular}

- The local market prices of the used ingredients were/ton of soybean meal (1350 L.E.), fish meal (5800 L.E), corn oil (3250 L.E.), yellow corn (750 L.E.), wheat bran, (600 L.E.), Jojoba meal, (700 L.E.), sunflower meal (1000 L.E.), Nigella sativa meal (850 L.E.), fish premix and vit. \& min., (9000 L.E.).

Total amount of feed intake $(\mathrm{kg} / \mathrm{tank})=$ feed intake $\times$ total fish intake.

Total feed costs $(\mathrm{L} . \mathrm{E})=$ price of one $\mathrm{kg}$ ration $\times$ total amount of feed intake

Total fish weight gain $/$ tank $(\mathrm{kg})=$ final weight - initial weight.

Total income / tank for fish weight gain (L.E) = Total fish weight gain / tank (kg) $\times$ sale price $\mathrm{kg}$ fish (L.E).

Revenues (L.E) = Total income / tank for fish weight gain - Total costs (L.E). 
Economical efficiency

$$
=\frac{\text { Total income }(\text { L.E. })}{\text { Total costs }(\text { L.E. })} \times 100
$$

These results indicate that incorporation of Jojoba meal to replace 50\% of soybean meal protein resulted in the lowest revenues. In general, results in Table (7) show that incorporation of Jojoba meal to replace 25\% of soybean meal protein improved the economical efficiency of Nile tilapia due to improvement in body weight. In this concern, Ali (2004) reported that the highest economical efficiency of tilapia was obtained using diets containing 25\% rumen contents and 25\% Jojoba meal in replacement with Soybean meal protein. $\mathrm{He}$ added that increasing level of Jojoba meal above 25\% decreased the economical efficiency. Averages of economical efficiency (Table 7) were 136.67; 142.64 and $126.62 \%$ for the control; $25 \%$ and 50\% Jojoba meal (treated) in replacement with soybean meal protein, respectively. Based on the obtained results, it is recommended to replace the soybean meal protein with treated Jojoba meal protein in growing Nile tilapia diets up to 25\% without adverse effects on growth performance and economic efficiency.

\section{REFERENCES}

Abbott, T. P.; Nakamra, L. K.; Nelsen, T. C.; Gasdorf, H. J.; Bennett, G. and Kleiman (2004). Microorganisms for degrading simmondsim and related cyanogenic toxins in Jojoba. Appl. Micro. Biotec. 34 (2): 270-273.

Ali, A. El-Makarem (2004). "Nutritional studies on fish performance under intensive production conditions." Ph.D. Thesis, Animal Production Dep., Fac. Agric, Ain Shams Univ.

A.O.A.C. (1984). Official Methods of Analysis. Association of Official Analytical Chemists. Washington, DC.

Bellirou, A.; Bouali, A.; Bouammali, B.; Boukhatem, N.; Elmtili, B.; Hamal, A. and El-Morabit, M. (2005). Extraction of simmondsin and oil in one from jojoba seeds. J. Ind. Crops and Products 21(2): 229 - 233.

Booth A.N.; Elliger, C.A. and Waiss, A.C. (1974). Isolation of a Toxic Factor from Jojoba Meal, Life Sci., 15: 11-15.

Boyd, C.E. (1979). "Water quality in warm water fish ponds." Ed. E. Claude Boyd, Third Ed., 1984, Pub. Auburn Univ., Agric. Exp. Station, AID/Dsan G.G., 39: 359pp. 
Cokelaere M.M.; Dangreau, H.D.; Daenens, P.; Bruneel, N.; Arnouts, S.; Decuypere, E. and Kühn, E.R. (1992). Investigation of possible toxicological influences of simmondsin after subacute administration in rat. J. Agric. feed Chem. 40: 2443- 2445.

Cotgageorge, A.G.; Price, R.L.; Weber, C.W. and Reid, B.L (1978). Detoxification of Jojoba Seed Meal, Third international Conference in Jojoba, held September 13-16, University of California, Riverside.

Duncan, D.B. (1955). Multiple range and multiple F-tests. Biomet. 11: 1.

El-Hamadany, E. (2001). Nutritive values of corn gluten meal and sesame seed meal in feed for hybrid tilapia (Oreochormis niloticus $x$ Oreochormis aureus). Egypt. J. Nutr. Feeds, 4 (1): 47-66.

Elliger, C.A.; Waiss, A.C. and Lundin, R.E. (1974). cyanomethylenecy-clohexyl Glucosides from Simmondsia californica phytochem. J. Chem. Soc., Perk, Trans, 13. 2319pp.

Elliger, C.A.; Waiss, A.C. and Lundin, RAE. (1973). Simmondsin. An Unusual 2-Cvanomethy Lenecyclohexyl Glucoside from Simmondsia californica, J. Chem. Soc., Perk. Trans., 1(19): 2209.

Jaime, W. (1987). The chemistry and technology of Jojoba oil. Washington, USA.

Jobling, M. (1983). A short review and cricique of methodology used in fish growth and nutrition studies. J. Fish. Biol. 23: 685-691.

Khalel, M. S.; Hassan, A. A.; Shwerabm, A. M. and Amany, A. Khayyam (2008). Feed evaluation of chemically and biologically treated Jojoba meal. Egypt. J. Nutr. Feeds, II (3): 481-495.

Motawe, H. F. (2005). Chemical evaluation of jojoba meal Egyptian J. Nutrition and Feeds 8 (1): 861-868.

Sabien, V.; Kirsten, D.; Gerda, F.; Marnix, C.; Mohammed, O. and Eddy, D. (1997). Effects of deoiled Jojoba meal on feed intake in chickens, stiating or taste effect. J. Agric. Food Chem, 45(8): 3158 - 3163.

Sales, J. and Janssens, G.P.J. (2006). A note on ash as indigestible dietary marker to determine digestibility of seeds in adult granivorous birds. J. Anim. Feed Sci., 12: 97-102. 
SAS (1996). "SAS Procedure Guide" “version 6.12 Ed”. SAS Institute Inc., Cary, NC, USA.

Van Boven, M.; Busson, R.; Cokelaere, M.; Flo, G. and Decuypere, E. (2000). Demethyl simmondsin from Simmondsia chinensis. Ind Crops Prod, 12: 203 - 208.

Verbiscar, A. J.; Banigan, T.F.; Weber, C.W.; Reid, B.L.; Trei, J.E.; Nelson, E.A.; Reffauf, R.F. and Kosersky, D. (1980). Detoxification of Jojoba meal. J. Agric. Feed Chem. 28: 571-578.

Winder, K. and Eggum, O. B. (1966). Protein hydrolysis. A description of the methods used at the Department of Animal Physiology in Copenhagen. Acta. Agric. Scandinavia, 16: 115pp.

Wisniak, J. (1987). The chemistry and technology of jojoba oil. Oil Chem. Soci, Champaign, Illinois. 